\title{
Influence of Calcium and Vitamin D Supplementation on Weight and Fat Loss in Obese Women
}

\author{
Michał Holecki $^{\mathrm{a}} \quad$ Barbara Zahorska-Markiewicz $^{\mathrm{a}}$ \\ Teresa Nieszporek ${ }^{\mathrm{b}}$ Agnieszka Żak-Gołąb ${ }^{\mathrm{a}}$ \\ a Department of Pathophysiology, \\ ${ }^{b}$ Department of Nephrology, Endocrinology and Metabolic Diseases, \\ ${ }^{\mathrm{c}}$ Department of Cardiology, Medical University of Silesia, Katowice, Poland
}

Andrzej Więcek $^{\mathrm{b}} \quad$ Katarzyna Mizia-Stec ${ }^{\mathrm{c}}$

\section{Key Words \\ Weight loss · Calcium · Vitamin D}

\section{Summary}

Background: Dairy products not only reduce the risk of hypertension and cardiovascular diseases but may play a role in the treatment of obesity. As there is some evidence that calcium ( $\mathrm{Ca}$ ) and vitamin $\mathrm{D}$ may play a role in effective weight management, we decided to evaluate the influence of $\mathrm{Ca}$ and vitamin $\mathrm{D}$ supplementation on weight and fat loss in obese women. Material and Methods: Forty obese women were enrolled in this study. Subjects were divided into 2 groups comparable with body mass index (BMI) and age. Group 1 was provided with calcium carbonate and 1-(OH)-vitamin D supplementation. Group 2 was provided with only a diet. Subjects participated in a 3-month weight reduction therapy (balanced diet, modification of life style, and regular physical exercise). Blood samples (serum concentration of Ca, phosphorus (P), parathormone (PTH), 25-(OH)- $\mathrm{D}_{3}$ ) and clinical characteristics (weight, height, BMI, body composition) were taken at baseline and after the 3month program. Results: No significant differences of body weight, body fat content, serum parathormone, 25- $(\mathrm{OH})-\mathrm{D}_{3}$ concentration, and plasma total $\mathrm{Ca}$ and $\mathrm{P}$ concentration were observed between analyzed groups both before and after the treatment. Additionally, we did not observe any significant influence of $\mathrm{Ca}$ and vitamin $\mathrm{D}$ supplementation on weight and fat loss. Conclusion: $\mathrm{Ca}$ plus vitamin D supplementation during a 3-month low caloric diet has no additional effect on weight and fat loss in obese women.

\section{Introduction}

Obesity is a chronic disorder of multi-factorial etiology, that is known as a major problem all over the world, and is one of the well-established risk factors of increased cardiovascular morbidity and mortality. Based on American data, it is a known fact that the proportion of obese women increased dramatically during the last decade of the 20th century (by nearly $50 \%$ ) [1]. Nowadays, prevention of weight gain should be the most important goal of public health. A combination of both dietary intervention and physical activity is the easiest and most common stragtegy of obesity treatment.

Dietary calcium $(\mathrm{Ca})$ intake plays an important role not only in the maintenance of skeletal integrity but also in modulating the risk of developing chronic diseases. Dairy products not only reduce the risk of hypertension and cardiovascular diseases but may also play a role in the treatment of obesity $[2,3]$. There is some evidence that $\mathrm{Ca}$ and vitamin $\mathrm{D}$ may be a decisive factor in effective weight management [4, 5]. A number of epidemiological studies have identified an inverse relationship between fat content and $\mathrm{Ca}$ intake [6-8], however, most interventional studies have not supported this finding, neither in adults nor in children [9-11]. As the topic is still controversial and results divergent, we decided to evaluate the influence of $\mathrm{Ca}$ and vitamin $\mathrm{D}$ supplementation on weight and fat loss in obese women again (a short overview of the current literature is given in table 1$)$.

\section{Material and Methods}

A total of 40 obese women were enrolled in this study. All of them were diagnosed with simple obesity without concomitant diseases. None of them had undergone ovariectomy. All subjects were informed about the nature of the study, and signed their informed consent forms. The inclusion criteria included body mass index $(\mathrm{BMI})>30 \mathrm{~kg} / \mathrm{m}^{2}$, age $45-55$ years,

\begin{tabular}{ll}
\hline KARGER & $\oplus$ 2008 S. Karger GmbH, Freiburg \\
Fax +497614520714 & Accessible online at: \\
Information@Karger.de & www.karger.com/ofa \\
www.karger.com &
\end{tabular}


Table 1. Mini-review of the literature including negative and positive effects of $\mathrm{Ca}$ and/or vitamin $\mathrm{D}$ supplementation on weight and/or fat loss

\begin{tabular}{llll}
\hline Reference & Objective & Results & Conclusion \\
\hline Lorenzen et al., 2006 [11] & $\begin{array}{l}\text { whether Ca supplementation } \\
\text { affects body weight and } \\
\text { body fat in young girls }(\mathrm{n}=110)\end{array}$ & $\begin{array}{l}\text { significant negative correlation } \\
\text { between habitual dietary Ca } \\
\text { intake and body fat }(\%) ;\end{array}$ & $\begin{array}{l}\text { Ca supplementation had no effect } \\
\text { on body weight, height, or body fat } \\
\text { ever 1 year in young girls } \\
\text { effect on weight and percentage } \\
\text { of body fat }\end{array}$ \\
& &
\end{tabular}

Kamycheva et al., 2003 [22] whether there is an association between $\mathrm{BMI}$ and $\mathrm{Ca}$ and vitamin D intake in 9,252 men and 9,662 women

Zhang et al., 2004 [19]

whether there is an effect of dietary $\mathrm{Ca}$ on body weight of lean and obese mice and rats

Boon et al., 2006 [20]

whether energy and substrate metabolism and adipose tissue mRNA expression may be altered by dietary $\mathrm{Ca}$ intake in healthy, non-obese volunteers $(\mathrm{n}=12)$

Zemel et al., 2004 [15] whether diary products or $\mathrm{Ca}$ accelerate weight and fat loss induced by caloric restriction $(\mathrm{n}=41)$

Melanson et al., 2003 [16]

whether total Ca intake and intake of Ca from dairy sources are related to whole body fat oxidation $(\mathrm{n}=35)$

Davies et al., 2000 [17] whether there is an association between $\mathrm{Ca}$ intake and body weight (analysis of 5 clinical studies $(\mathrm{n}=780)$

Heaney et al., 2002 [18]

to evaluate the effect of Ca intake on body weight and body fat; data from 6 observational studies and 3 controlled studies

Lin et al., 2000 [33]

investigation of relationship between micronutrients and dairy product intake and changes in body weight and composition over a period of 2 years $(n=54)$

Lovejoy et al., 2001 [34]

to compare dietary intake and energy expenditure between middle-aged, premenopausal African American $(\mathrm{n}=97)$ and Caucasian women (54)

Garrow et al., 1989 [35]

to measure total weight and lean tissue loss in obese women, comparing 2 diets - one a mixedfood, energy-restricted diet, and the other consisting solely of milk

positive correlation between BMI

and $\mathrm{Ca}$ intake in men but not in

women;

negative relationship between

$\mathrm{BMI}$ and vitamin D in both sexes

no effects of Ca manipulation on energy intake, body weight, or carcass fat content; no simple relation between calcitropic hormones and body weight

no significant differences in

24-h energy expenditure and

fat oxidation between analyzed

patients;

no significant differences in gene

expression in proteins between analyzed patients

Ca and vitamin D may have opposing effects on body weight

loss of body fat was increased by high-Ca diet;

fat loss was augmented by high-Ca and high-diary dieta

Ca intake was positively correlated with fat oxidation over $24 \mathrm{~h}$, during sleep and during light physical activity;

$\mathrm{Ca}$ intake from dairy sources was similarly correlated with fat oxidation

no effect of dietary Ca on body weight of lean and obese mice and rats

dietary Ca content for 7 days does not influence substrate metabolism, energy metabolism, or gene expression in proteins related to fat despite changes in $1.25(\mathrm{OH})_{2}$ vitamin $\mathrm{D}$ concentration

increased dietary Ca significantly augmented weight and fat loss secondary to caloric restriction

higher Ca intake is associated with higher rates of whole body fat oxidation; effects were apparent over $24 \mathrm{~h}$, during sleep and, to a lesser extent, during light physical activity

1,000-mg difference in Ca intake is associated with $8-\mathrm{kg}$ difference in mean body weight; Ca intake explains approximately $3 \%$ of the variance in body weight

each 300-mg increment in regular Ca intake is associated with approximately $1 \mathrm{~kg}$ less body fat in children and 2.5-3.0 kg lower body weight in adults

significant inverse correlation between Ca intake, adjusted for energy, and change in both body weight and body fat mass

increased $\mathrm{Ca}$ intake was consistently associated with reduced indices of adiposity

consistent effect of higher Ca intake, expressed as lower body fat and/or body weight and reduced weight gain in midlife

subjects with high Ca intake, corrected for total energy intake and lower vitamin A intake, gained less weight and body fat over 2 years

inverse correlation between $\mathrm{Ca}$ intake and both BMI and percent body fat in Caucasian but not paper does not provide the information needed to estimate the extent of the Ca effect

African-American women

weight loss was not significantly different for the 2 regimens, but milk diet resulted in substantially less lean tissue loss high milk intake increases the effectiveness of a weight reduction program 
stable body weight over the last 3 months, no evidence of present or recent (last 3 months) infectious diseases or drug therapy, correct lipid profile and fasting serum glucose level. Exclusion criteria included smoking cigarettes and drinking more than 2 alcoholic drinks a week.

Subjects were divided into 2 groups comparable with BMI and age. Group 1 comprised 20 obese women (mean body weight $91.2 \pm 12.5 \mathrm{~kg}$; BMI 36.9 $\pm 5.0 \mathrm{~kg} / \mathrm{m}^{2}$; mean age $51.6 \pm 6.5$ years) who were provided with calcium carbonate $(2 \times 1,000 \mathrm{mg})$ and $1-(\mathrm{OH})$-vitamin $\mathrm{D}(0.25 \mu \mathrm{g}$ per day $)$ supplementation. Group 2 comprised 20 obese women (mean body weight $96.1 \pm$ $12.2 \mathrm{~kg}$; BMI $35.4 \pm 4.48 \mathrm{~kg} / \mathrm{m}^{2}$; mean age $49.1 \pm 4.8$ years) who were provided with only a diet. All of these subjects participated in a 3-month weight reduction therapy that consisted of a 1,000-1,200 kcal/day balanced diet (daily Ca consumption $500 \mathrm{mg}$ ), modification of lifestyle, and regular physical exercise (60 min, 3 times a week). Each patient was evaluated every 2 weeks by a doctor and a dietician. Each patient was asked to keep a dietetic diary. Patients from group 1 were provided with exact amounts of tablets (28 calcium carbonate tablets and $140.25-\mu \mathrm{g}$ vitamin D tablets) at each visit.

Blood samples and clinical characteristics were taken at baseline and after the 3-month program. Body weight and height were measured, and BMI was calculated. Body composition was analyzed using the bioimpedance method (Bodystat 1500; Bodystat Ltd., Douglas, Isle of Man, British Isles). In all patients, before and after the 3-month weight reduction therapy, serum concentrations of $\mathrm{Ca}$, phosphorus $(\mathrm{P})$, parathormone $(\mathrm{PTH})$, and $25-(\mathrm{OH})-\mathrm{D}_{3}$ were assessed. Blood samples were taken from each subject in the morning between 8.00 and $9.00 \mathrm{am}$, after an overnight fast. After clot formation, the samples were centrifuged $(1,000 \times g)$ at room temperature for $10 \mathrm{~min}$. The serum obtained was drawn into plastic vials and stored at $-80^{\circ} \mathrm{C}$ until the time of the assay. In our study, we did not take into consideration seasonal variation of parameters of the Ca-P metabolism, as the therapy was run from October to December. Usually, in women, the serum $25-(\mathrm{OH})-\mathrm{D}_{3}$ concentration decreases (approximately $20 \%$ ) in winter, and returns to baseline levels in the summer [6].25-(OH)$\mathrm{D}_{3}$ was measured using the RIA method (BioSource Europe S.A., Nivelles, Belgium). The Electrochemiluminiscent ImmunoAssay 'ECLIA' (Roche, Meylan, France) was used for PTH assay. Total Ca and P were measured using a spectrophotometer. All values are expressed as means \pm standard deviation (SD).

Statistical analyses were performed using the STATISTICA computer program (StatSoft Inc., Tulsa, OK, USA). The results were analyzed using the Kolmogorov-Smirnoff test and Spearman's correlation analysis. $p$ values $<0.05$ were considered to be significant.

\section{Results}

In group 1, the mean weight loss was $7.0 \pm 2.6 \mathrm{~kg}(7.8 \pm 2.0 \%)$. BMI decreased from $36.9 \pm 5.0 \mathrm{~kg} / \mathrm{m}^{2}$ at baseline to $34.1 \pm 4.5$ $\mathrm{kg} / \mathrm{m}^{2}$ post-treatment (table 1 ). After weight reduction in obese subjects, $\mathrm{P}$ serum concentration significantly decreased. However, no significant changes of serum PTH, 25-(OH)- $\mathrm{D}_{3}$ concentration, and total plasma $\mathrm{Ca}$ concentration were observed after weight loss (tables 2,3) (figs. 1, 2). After treatment, a negative correlation was found between body weight and $25-(\mathrm{OH})-\mathrm{D}_{3}$ serum concentration $(\mathrm{r}=-0.75 ; \mathrm{p}=0.0001)$. In group 2, the mean weight loss was $8.4 \pm 3.7 \mathrm{~kg}(10.2 \pm$ $4.5 \%$ ). BMI decreased from $35.4 \pm 4.4 \mathrm{~kg} / \mathrm{m}^{2}$ at baseline to $32.1 \pm 4.2 \mathrm{~kg} / \mathrm{m}^{2}$ post-treatment (table 2 ). Serum concentrations of PTH and 25-(OH)- $\mathrm{D}_{3}$, and plasma total Ca and P concentration did not change significantly after weight reduction therapy (tables 2, 3) (figs. 3, 4).
Table 2. Results of weight reduction therapy in obese women from group 1 (diet plus supplementation) and group 2 (diet only)

\begin{tabular}{|c|c|c|c|c|}
\hline & $\begin{array}{l}\text { Group } 1 \\
\text { mean } \pm \text { SD }\end{array}$ & $\Delta$ & $\begin{array}{l}\text { Group } 2 \\
\text { mean } \pm \mathrm{SD}\end{array}$ & $\Delta$ \\
\hline \multicolumn{5}{|l|}{ Weight, kg } \\
\hline $\begin{array}{l}\text { Before } \\
\text { After }\end{array}$ & $\begin{array}{l}96.1 \pm 12.2 \\
89.1 \pm 11.7^{\mathrm{a}}\end{array}$ & $7.0 \pm 2.6$ & $\begin{array}{l}91.2 \pm 12.5 \\
82.7 \pm 11.5^{\mathrm{a}}\end{array}$ & $8.4 \pm 3.7$ \\
\hline \multicolumn{5}{|c|}{ BMI, $\mathrm{kg} / \mathrm{m}^{2}$} \\
\hline $\begin{array}{l}\text { Before } \\
\text { After }\end{array}$ & $\begin{array}{l}36.9 \pm 5.05 \\
34.1 \pm 4.5^{\mathrm{a}}\end{array}$ & $2.8 \pm 1.2$ & $\begin{array}{l}35.4 \pm 4.48 \\
32.1 \pm 4.2^{\mathrm{a}}\end{array}$ & $3.3 \pm 1.4$ \\
\hline \multicolumn{5}{|c|}{ Fat content, \% } \\
\hline $\begin{array}{l}\text { Before } \\
\text { After }\end{array}$ & $\begin{array}{l}50.3 \pm 6.7 \\
44.5 \pm 5.4^{\mathrm{a}}\end{array}$ & $5.8 \pm 9.9$ & $\begin{array}{l}48.5 \pm 8.5 \\
41.5 \pm 5.7^{\mathrm{a}}\end{array}$ & $7.0 \pm 6.0$ \\
\hline
\end{tabular}

${ }^{\mathrm{a}} \mathrm{p}<0.0001$ before vs. after.

Table 3. Serum levels of $\mathrm{PTH}, 25-(\mathrm{OH})-\mathrm{D}_{3}, \mathrm{Ca}$, and $\mathrm{P}$ before and after weight reduction therapy in obese women from group 1 (diet plus supplementation ) and group 2 (diet only)

\begin{tabular}{|c|c|c|c|c|}
\hline & $\begin{array}{l}\text { Group } 1 \\
\text { mean } \pm \text { SD }\end{array}$ & $\Delta$ & $\begin{array}{l}\text { Group } 2 \\
\text { mean } \pm \text { SD }\end{array}$ & $\Delta$ \\
\hline \multicolumn{5}{|c|}{$\mathrm{PTH}, \mathrm{pg} / \mathrm{ml}$} \\
\hline Before & $53.5 \pm 21.1$ & \multirow{2}{*}{$5.1 \pm 17.7$} & $49.6 \pm 14.3$ & \multirow{2}{*}{$5.7 \pm 16.3$} \\
\hline After & $48.4 \pm 19.3$ & & $43.9 \pm 11.7$ & \\
\hline \multicolumn{5}{|c|}{$25-(\mathrm{OH})-\mathrm{D}_{3}, \mathrm{ng} / \mathrm{ml}$} \\
\hline Before & $25.3 \pm 13.0$ & \multirow{2}{*}{$4.11 \pm 9.2$} & $35.2 \pm 16.2$ & \multirow{2}{*}{$3.7 \pm 8.8$} \\
\hline After & $29.4 \pm 11.5$ & & $38.9 \pm 18.2$ & \\
\hline \multicolumn{5}{|c|}{$\mathrm{Ca}, \mathrm{mmol} / \mathrm{l}$} \\
\hline Before & $2.2 \pm 0.1$ & \multirow{2}{*}{$0.05 \pm 0.1$} & $2.3 \pm 0.1$ & \multirow{2}{*}{$0.001 \pm 0.07$} \\
\hline After & $2.3 \pm 0.1$ & & $2.3 \pm 0.1$ & \\
\hline \multicolumn{5}{|l|}{$\mathrm{P}, \mathrm{mmol} / \mathrm{l}$} \\
\hline Before & $1.2 \pm 0.2$ & \multirow{2}{*}{$0.12 \pm 0.2$} & $1.1 \pm 0.2$ & \multirow{2}{*}{$0.07 \pm 0.3$} \\
\hline After & $1.0 \pm 0.1^{\mathrm{a}}$ & & $1.2 \pm 0.2$ & \\
\hline
\end{tabular}

${ }^{\mathrm{a}} \mathrm{p}<0.05$ before vs. after.

\section{Group 1 versus Group 2}

No significant differences of body weight, body fat content, serum PTH and 25- $(\mathrm{OH})-\mathrm{D}_{3}$ concentration, plasma total $\mathrm{Ca}$ and $\mathrm{P}$ concentration were observed between analyzed groups both before and after the treatment. Additionally, we did not observe any significant influence of $\mathrm{Ca}$ and vitamin $\mathrm{D}$ supplementation on weight and fat loss (tables 2,3).

\section{Discussion}

In the last few years, much attention has been paid to the 'anti-obesity' influence of $\mathrm{Ca}$ and dairy food [12]. It was observed that a restricted but $\mathrm{Ca}$-rich diet was associated with marked augmentation of body mass and fat loss in both mice 
Fig. 1. Results of weight reduction therapy in obese women from group 1 (diet plus supplementation); * $\mathrm{p}>0.001$
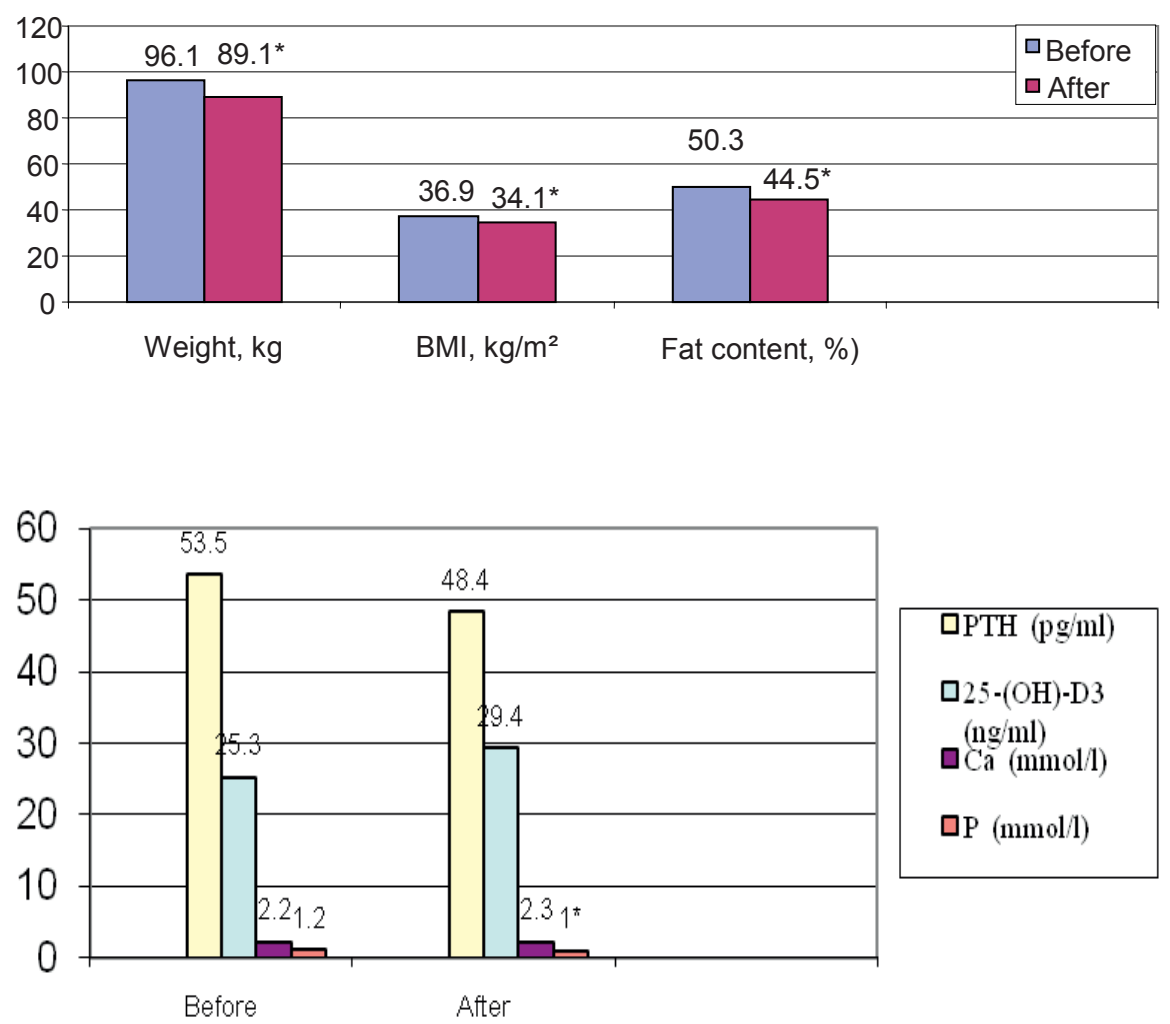

Fig. 2. Serum levels of $\mathrm{PTH}, 25-(\mathrm{OH})-\mathrm{D}_{3}, \mathrm{Ca}$ and $\mathrm{P}$ before and after weight reduction therapy in obese women from group $1 ; * \mathrm{p}>0.05$.
Fig. 3. Results of weight reduction therapy in obese women from group $2 ; * \mathrm{p}>0.0001$.

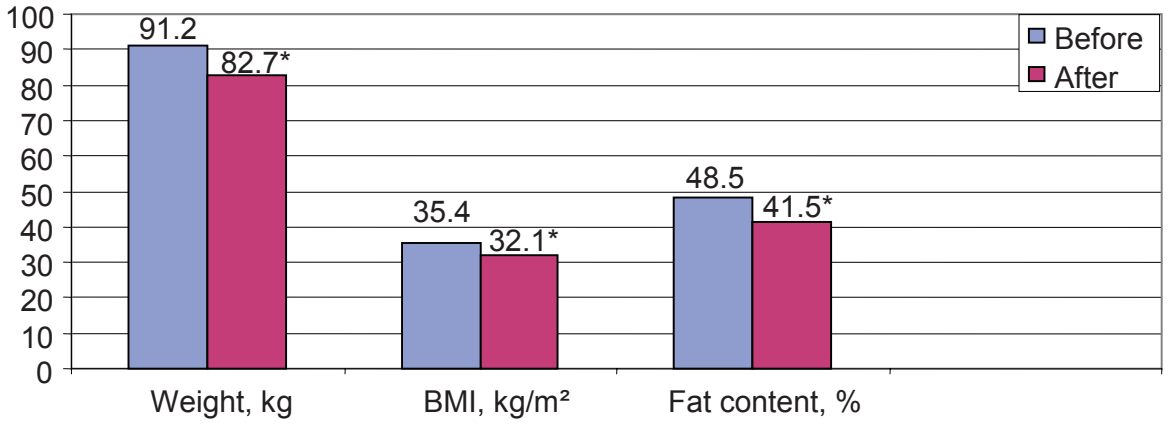

and humans $[13,14]$. In another study [15], it was found that an increase in dietary $\mathrm{Ca}$ content (during a restrictive diet) from 400 to $1,200 \mathrm{mg}$ a day was associated with a 26 and $38 \%$ increase in weight and fat loss, respectively. Moreover, a Caand dairy-rich diet resulted in a 50-66\% increase in total fat loss from the trunk region in comparison to $19 \%$ on a low-Ca diet [15]. There are many other data that support the anti-obesity effect of Ca supplementation. Melanson et al. [16] reported a positive correlation between $\mathrm{Ca}$ intake and whole body fat oxidation both during sleep and during moderate physical activity. Davies et al. [17] and Heaney et al. [18] who analyzed data from 9 studies reported that $\mathrm{Ca}$ intake was associated with reduced indices of adiposity. They observed that an increase in daily Ca intake by $300 \mathrm{mg}$ was associated with a $3-\mathrm{kg}$ lower weight in adults.
However, the results of other studies contradict the abovementioned data. Zhang and Tordoff [19] found no effects of Ca manipulation in the diet on energy intake and body weight, and no simple relationship between calcitropic hormones and body weight. Boon et al. [20] reported that dietary Ca content does not influence substrate metabolism, energy metabolism, or gene expression in proteins related to fat metabolism. In another study, Boon et al. [21] (who evaluated the effects of increasing serum calcitriol on energy and fat metabolism and gene expression) did not observe any significant differences in substrate and energy metabolism or mRNA concentrations of different lipid metabolism-related proteins despite a significant increase in serum 1.25-(OH)- $\mathrm{D}_{3}$ concentration. A Norwegian cross-sectional study [22] reported a positive correlation between $\mathrm{Ca}$ and $\mathrm{BMI}$ in men but no 


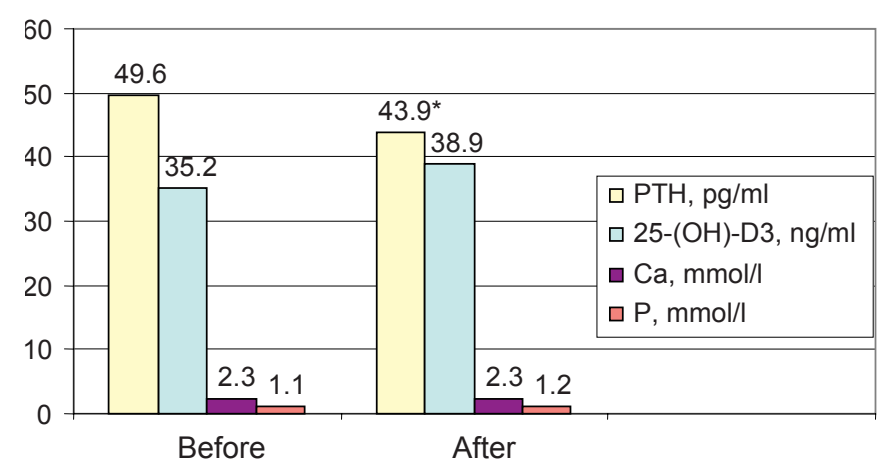

Fig. 4. Serum levels of $P T H, 25-(\mathrm{OH})-\mathrm{D}_{3}, \mathrm{Ca}$, and $\mathrm{P}$ before and after weight reduction therapy in obese women from group $2 ; * \mathrm{p}>0.05$.

association of Ca and BMI in women. Shapes et al. [23] examined whether Ca supplementation affects body weight during weight loss therapy. They found no significant changes of body weight or body fat during a 25 -week weight loss treatment with supplementation of $1 \mathrm{~g}$ calcium citrate malate. Lorenzen et al. [11] indicates that Ca supplementation for 1 year does not reduce body weight or fat mass. Also Lorenzen et al. [24] indicated that $\mathrm{Ca}$ did not affect appetite sensation, glucose metabolism, or gut hormone secretion. In agreement with previous studies, Caan et al. [25] also reported a minor effect of combined therapy of Ca plus cholecalciferol in the prevention of weight gain.

These results are in agreement with the results obtained in this study. We, too, did not find any significant influence of $\mathrm{Ca}$ and vitamin D supplementation on weight and fat loss. As the results of this and other studies are inconsistent, we claim that the influence of $\mathrm{Ca} /$ vitamin $\mathrm{D}$ supplementation on both prevention of weight gain and loosing weight is still controversial and not fully established. We agree with Caan et al. [25] that 'further research should be undertaken to address the effect of $\mathrm{Ca}$ supplementation combined with caloric restriction and physical activity on weight gain protection'. However, we wonder if $\mathrm{Ca}$ per se or diary products really affect body weight. The fact that a short-term increase in dietary Ca intake increases energy excretion (350 kJ/day) [26] may explain why a high-Ca diet produces weight loss. Maybe the explanation is that the source of $\mathrm{Ca}$ is more important and influences the effect on body weight. Zemel $[27,28]$ pointed out that Ca from dairy products has a more profound effect on weight and fat loss compared to that found with Ca supplementation per se. This finding suggests that the effect is likely due to additional bioactive compounds which are found in dairy products. This additional factor in dairy may act independently or synergistically with $\mathrm{Ca}$ to block lipogenesis and promote lipolysis, but the mechanisms of this additional dairy effect are not clear. What mechanisms underlie the changes mentioned above? The biological observations proved that a combination of $\mathrm{Ca}$ and vitamin $\mathrm{D}$ in the diet may regulate lipid metabolism in adipose tissue (mainly by influence on fatty acid oxidation and lipogenesis) [2, 29]. In 2004, Zemel et al. [13, 15] proposed an explanation for this phenomenon. The authors suggest that increased serum concentrations of $1.25-(\mathrm{OH})-\mathrm{D}_{3}$, as an effect of a low-Ca diet, enhance the intracellular Ca flow (via a specific membrane vitamin D receptor). High Ca concentrations in adipocytes may stimulate lipogenesis (stimulation of lipogenic gene expression) and suppress lipolysis. Additionally, calcitriol may also suppress the expression of adipocyte uncoupling protein 2 (UCP2), and in that way limit mitochondrial fatty acid transport and oxidation [29]. In contrast, an opposite situation may happen. Increased $\mathrm{Ca}$ content in a diet may suppress serum calcitriol levels, resulting in reduction of lipogenic gene expression and promotion of lipolysis and UCP2 gene expression, and in that way reducing lipid filling and adiposity. Moreover, Ca may decrease fatty acid absorption in the intestine and increase fecal fat loss [13,30-32].

At present, we do know that adipocytes have an autocrine/ paracrine renin-angiotensin system and that adipocyte lipogenesis is partly regulated by angiotensin II [16]. Therefore, angiotensin-converting enzyme inhibitors, which are found in dairy, may act together with Ca to attenuate adiposity [28]. We speculate that the goal of future investigations should be the influence of diary products (that are rich in $\mathrm{Ca}$ ) on body weight and fat content during weight reduction therapy. All these matters need further investigation.

\section{Conclusion}

Ca plus vitamin D supplementation during a 3-month period of low caloric diet has no additional effect on weight and fat Coss in obese women.

\section{References}

1 Centers for Disease Control and Prevention (CDC): Behavioral Risk Factor Surveillance System Survey Data. Atlanta, GA, Dept of Health and Human Services CDC, 2000.

2 Appel LJ, Moore TJ, Obarzanek E, et al: A clinical trial of the effects of dietary patterns on blood pressure. DASH Collaborative Research Group. N Engl J Med 1997;336:1117-1124.

3 McCarron DA, Reusser ME: Finding consensus in the dietary calcium-blood pressure debate. J Am Coll Nutr 1999;18:398-405.
4 Zemel MB: Calcium modulation of hypertension and obesity: mechanisms and implications. Am Coll Nutr 2001;20:428-435.

5 Zemel MB, Shi H, Greer B, et al: Regulation of adiposity by dietary calcium. FASEB J 2000;14: 1132-1138.

6 Carruth BR, Skinner JD: The role of dietary calcium and other nutrients in moderating body fat in preschool children. Int J Obes Relat Metab Disord 2001;25:559-566.
7 Lin YC, Lyle RM, McCabe LD, McCabe GP, et al: Dairy calcium is related to changes in body composition during a two-year exercise intervention in young women. J Am Coll Nutr 2000;19:754-760.

8 McCarron DA: Calcium and magnesium nutrition in human hypertension. Ann Intern Med 1983;98: 800-805.

9 Trowman R, Dumville JC, Hahn S, Torgerson DJ: A systematic review of the effects of calcium supplementation on body weight. Br J Nutr 2006;95: 1033-1038. 
10 Reid IR, Horne A, Mason B, et al: Effects of calcium supplementation on body weight and blood pressure in normal older women: a randomized controlled trial. J Clin Endocrinol Metable 2005;90: 3824-3829.

11 Lorenzen JK, Mølgaard C, Michaelsen KF, et al Calcium supplementation for $1 \mathrm{y}$ does not reduce body weight or fat mass in young girls. Am J Clin Nutr 2006;83:18-23.

12 Storm D, Eslin R, Porter ES, et al: Calcium supplementation prevents the seasonal bone loss and changes in biochemical markers of bone turnover in elderly New England women: a randomized placebo-controlled trial. J Clin Endocrinol Metab 1998;83:3817-3825.

13 Zemel MB: Role of calcium and dairy products in energy partitioning and weight management. Am J Clin Nutr 2004;79:907-912.

14 Shi H, DiRienzo D, Zemel MB: Effects of dietary calcium on adipocyte lipid metabolism and body weight regulation in energy-restricted aP2-agout transgenic mice. FASEB J 2001;15:291-293.

15 Zemel MB, Thompson W, Milstead A, et al: Calcium and dairy acceleration of weight and fat loss during energy restriction in obese adults. Obes Res 2004;12:582-590.

16 Melanson EL, Sharp TA, Schneider J, et al: Relation between calcium intake and fat oxidation in adult humans. Int J Obes Relat Metab Disord 2003 27:196-203.

17 Davies KM, Heaney RP, Recker RR, et al: Calcium intake and body weight. J Clin Endocrinol Metab 2000;85:4635-4638.

18 Heaney RP, Davies KM, Barger-Lux MJ: Calcium and weight: clinical studies. J Am Coll Nutr 2002;21: $152-155$.
19 Zhang Q, Tordoff MG: No effect of dietary calcium on body weight of lean and obese mice and rats. Am J Physiol Regul Integr Comp Physiol 2004;286: 669-677.

20 Boon N, Hul GBJ, Viguerie N, et al: The effect of three diets with varying calcium contents on 24hour energy-expanditure, 24-hour fat oxidation and adipose tissue mRNA expression of lipid metabolism related proteins. Am J Clin Nutr 2005;82: 1244-1252.

21 Boon N, Hul GB, Sicard A, et al: The effects of increasing serum calcitriol on energy and fat metabolism and gene expression. Obesity 2006;14: 1739-1746.

22 Kamycheva E, Joakimsen RM, Jorde R: Intakes of calcium and vitamin D predict body mass index in the population of Northern Norway. J Nutr 2003; 133:102-106.

23 Shapses SA, Heshka S, Heymsfield SB: Effect of calcium supplementation on weight and fat loss in women. J Clin Endocrinol Metab 2004;89:632-637.

24 Lorenzen JK, Nielsen S, Holst JJ, et al: Effect of dairy calcium or supplementary calcium intake on postprandial fat metabolism, appetite, and subsequent energy intake. Am J Clin Nutr 2007;85: 678-687.

25 Caan B, Neuhouser M, Aragaki A, et al: Calcium plus vitamin D supplementation and the risk of postmenopausal weight gain. Arch Intern Med 2007;167:893-902.

26 Jacobsen R, Lorenzen JK, Toubro S, et al: Effect of short-term high dietary calcium intake on 24-h energy expenditure, fat oxidation, and fecal fat excretion. Int J Obes 2005;29:292-301.
27 Zemel MB, Gen X: Dietary calcium and yogurt accelerate body fat loss secondary to caloric restriction in aP2-agouti transgenic mice. Obesity Res 2001;9:146(abstr).

28 Zemel MB: Role of dietary calcium and dairy products in modulating adiposity. Lipids 2003;38: 139-146.

29 Shi H, Norman AW, Okamura WH, et al: $1 \alpha, 25$ Dihydroxyvitamin D3 modulates human adipocyte metabolism via nongenomic action. FASEB J 2001; 15:2751-2753.

30 Parikh S, Yanowski J: Calcium intake and adiposity Am J Clin Nutr 2003;17:282-287.

31 Zemel MB: Regulation of adiposity and obesity risk by dietary calcium: mechanisms and implications. J Am Coll Nutr 2002;21:146-151.

32 Teegarden D, Zemel MB: Dairy product components and weight regulation: symposium overview. J Nutr Jan 2003;133:243-244.

33 Lin YC, Lyle RM, McCabe LD, et al: Dairy calcium is related to changes in body composition during a two-year exercise intervention in young women. $\mathrm{J}$ Am Coll Nutr 2000;19:754-760.

34 Lovejoy JC, Champagne CM, Smith SR, et al: Ethnic differences in dietary intakes, physical activity, and energy expenditure in middle-aged, premenopausal women: the Healthy Transitions Study. Am J Clin Nutr 2001;74:90-95.

35 Garrow JS, Webster JD, Pearson M, et al: Inpatientoutpatient randomized comparison of Cambridge diet versus milk diet in 17 obese women over 24 weeks. Int J Obesity 1989;13:521-529. 